\title{
DETERMINAN OBESITAS PADA ANAK USIA SEKOLAH ( Studi di SD Al-Irsyad 01 - 02 Cilacap Tahun 2018 )
}

\section{DETERMINANT OF OBESITY IN SCHOOL - AGE CHILDREN ( Study in Elementary School Al-Irsyad 01-02 Cilacap 2018 )}

\author{
Sarwa ${ }^{1)}$ Agus Prasetyo ${ }^{2)}$ \\ 1) Prodi D3 Keperawatan STIKES Al-Irsyad Al-Islamiyyah Cilacap \\ ${ }^{2)}$ Prodi S1 Keperawatan STIKES Al-Irsyad Al-Islamiyyah Cilacap
}

\section{INFO ARTIKEL}

Kata Kunci : Obesitas, Anak, AKG, Energi

Key Word : Obesity, Children, RDA, Energy

\begin{abstract}
ABSTRAK/ABSTRACT
Prevalensi anak obesitas di Indonesia cenderung mengalami peningkatan. Berdasarkan data RISKESDAS Provinsi Jawa Tengah Tahun 2010 menunjukan prevalensi obesitas pada anak usia sekolah (10-12 tahun) mencapai 10,9\%. Tujuan penelitian ini untuk mengetahui determinan obesitas pada anak usia sekolah. Penelitian ini merupakan jenis penelitian kuantitatif dengan desain case control. Sampel penelitian adalah anak SD usia 10-12 tahun sebanyak 60 sampel yang terdiri dari 30 orang kasus, yaitu anak dengan obesitas dan 30 orang kontrol, yaitu anak dengan berat badan normal. Variabel penelitian meliputi obesitas sebagai variabel dependen dan jenis kelamin, ayah obesitas, ibu obesitas, ayah dan ibu obesitas, pendidikan orang tua, dan asupan energi harian sebagai variabel independen. Pengambilan sampel secara purposive sampling. Analisa data multivariat dengan uji statistik regressi logistic. Hasil penelitian menunjukkan variabel yang mempunyai hubungan bermakna secara statistik dengan kejadian obesitas pada anak usia sekolah adalah asupan energi harian melebihi AKG $(p v=0,001)$, ibu obesitas $(p v=0,013$ pada $\alpha=0,05)$, dan ayah obesitas $(p v=0,024$ pada $\alpha=0,05)$. Determinan obesitas pada anak usia sekolah adalah asupan energi harian yang melebihi AKG (> $2.000 \mathrm{kkal} / \mathrm{hari})$.
\end{abstract}

The prevalence of child obesity in Indonesia trends to increase. Based on the data from Riskesdas Central Java Province in 2010 shows the prevalence of obesity in school-age children ( 10 -12 years old) reaches 10,9\%. This study aims to know the determinant of obesity in school-age children. The study applied a quantitative approach with a case-control design. Sixty students with age of 10 - 12 years old were taken out as this research sample which was consisted of 30 cases of childhood obesity and 30 control group of normal weight children. The research variable is obesity as dependent variable and gender, father obesity, mother obesity, father and mother obesity, parental education, and daily energy intake as the independent variable. The sample was taken by purposive sampling. Multivariate data analysis was performed by binary logistic regression statistical tests using the backward-wald methods. The results showed a variable that had a statistically significant relationship with the incidence of obesity in school - age children was the daily energy intake exceeding the RDA ( $p v=0,001$ at $\alpha=0,05)$, mothers obesity $(p v=0,013$ at $\alpha$ $=0,05$ ) and father obesity ( $p v=0,024$ at $\alpha=0,05$ ). The determinant of obesity in school-age children is a daily energy intake that exceeds the RDA (> $2.000 \mathrm{kcal} / \mathrm{day})$. 


\section{A. PENDAhULUAN}

Obesitas merupakan keadaan patologis, yaitu terdapatnya penimbunan lemak yang berlebihan dari yang diperlukan. Obesitas terjadi akibat asupan energi lebih tinggi daripada energi yang dikeluarkan. Asupan energi tinggi disebabkan oleh konsumsi makanan sumber energi dan lemak tinggi, sedangkan pengeluaran energi yang rendah disebabkan karena kurangnya aktivitas fisik dan sedentary life style (Kemenkes RI, 2010). Masalah obesitas dapat terjadi pada semua kelompok umur dan pada semua strata sosial ekonomi. Meskipun dapat terjadi di semua kelompok umur, obesitas dianggap sebagai kelainan pada umur pertengahan (Misnadiarly, 2007). Penentu kegemukan masa kecil dan obesitas di China mengungkapkan bahwa anak-anak yang kelebihan berat badan, lebih tinggi dalam tingkat konsumsi energi, protein dan lemak namun lebih sedikit dalam mengkonsumsi karbohidrat dari berat normal mereka. Kelebihan energi setiap hari secara rutin pada anak sekolah dapat menimbulkan timbunan lemak tubuh menjadi bertambah (Nadhiroh, dkk, 2012).

Menurut penelitian Misnadiarly, 2007, obesitas yang muncul pada tahun pertama kehidupan biasanya disertai perkembangan rangka yang cepat dan anak menjadi besar untuk umurnya. Obesitas pada anak sering dijumpai dalam keluarga mampu dan jenis kelamin juga berperan dalam timbulnya obesitas. Obesitas lebih umum dijumpai pada wanita, apalagi pada masa pertumbuhan pada anak-anak.

Obesitas pada anak sekolah merupakan masalah yang serius karena akan berlanjut hingga usia dewasa dan merupakan faktor risiko terjadinya berbagai penyakit metabolik dan degeneratif diantaranya penyakit kardiovaskuler, diabetes mellitus, kanker, osteoarthritis. Pada anak, obesitas juga dapat mengakibatkan berbagai masalah kesehatan yang sangat merugikan kualitas hidup anak seperti gangguan pertumbuhan tungkai kaki, gangguan tidur, sleep apnea dan gangguan pernafasan lain (Kemenkes RI, 2011).

Hasil Riskesdas Tahun 2010, dalam Pedoman Pencegahan dan Penanggulangan Kegemukan dan Obesitas pada Anak Sekolah Tahun 2012 secara nasional prevalensi kegemukan dan obesitas pada anak sekolah (6-12 tahun) adalah sebesar 9,2\% dan Provinsi Jawa Tengah berada di atas prevalensi nasional yaitu sebesar 10,9\% (Kemenkes RI, 2011).

Data Prevalensi Kurus dan Berat Badan Lebih Anak Umur 6-14 Tahun 2013 di Kabupaten Cilacap terjadi peningkatan 4,9\% dari Tahun 2007 yang sebesar 3,2\% (Dinkes Kabupaten Cilacap, 2016). 
Studi pendahuluan dilakukan di SD Al Irsyad 01-02 Cilacap tahun 2017. Hal ini karena sekolah ini merupakan salah satu SD favorit yang diminati masyarakat di Kota Cilacap. Biaya pendidikannya kategori tinggi sehingga pada umumnya anak yang bersekolah di sekolah tersebut berasal dari golongan ekonomi menengah keatas. Keadaan ekonomi yang memadai ini memungkinkan anak mempunyai gaya hidup dan pola makan yang beragam. Observasi kualitatif yang dilakukan didapatkan fenomena anak dengan tampilan fisik gemuk cenderung memilih pergi ke kantin di lingkungan sekitar sekolah dibanding melakukan aktifitas bermain dan membeli makanan dengan porsi serta jenis makanan yang berlebih, seperti memesan porsi makan dengan nasi double dan lauk pauk 3 sampai 5 potong.

Penelitian ini bertujuan untuk mengetahui determinan obesitas pada anak usia sekolah dari variabel-variabel yang diduga berhubungan dengan obesitas pada anak usia sekolah, yaitu : jenis kelamin, riwayat obesitas pada ibu, riwayat obesitas pada ayah, riwayat oebsitas pada ibu dan ayah, pendidikan orang tua, dan asupan energi harian.

\section{B. METODE}

Rancangan penelitian yang digunakan adalah case control, yaitu suatu penelitian yang mempelajari faktor resiko dengan pendekatan retrospektif, artinya penelitian dimulai dengan mengindentifikasi kelompok yang terkena efek tertentu (kasus) dan kelompok tanpa efek (kontrol) kemudian mengidentifikasi faktor risiko terjadinya pada waktu yang lalu, sehingga dapat menerangkan mengapa kasus terkena efek, sedangkan kontrol tidak terkena efek (Riyanto, 2011).

Penelitian dilakukan di SD Al Irsyad 01-02 Cilacap. Populasi dalam penelitian ini adalah semua anak SD Al Irsyad 0102 Cilacap tahun pelajaran 2017/2018, umur 10-12 tahun berjumlah 556 anak. Sampel sebagai kasus adalah anak yang mengalami obesitas berjumlah 30 anak dan control adalah anak dengan berat badan normal berjumlah 30 anak. Pengambilan sampel menggunakan teknik purposive sampling dengan kriteria umur 10-12 tahun yang mengalami obesitas dan yang berat badan normal, orang tua dan anak bersedia menjadi responden. Teknik pengumpulan data primer dengan cara menimbang berat badan anak, mengukur tinggi badan anak, dan pola makan sehari-hari melalui pemberian kuesioner Food Frequency Questionaire (FFQ). Data sekunder diperoleh dari lingkungan sekolah meliputi nama anak, jenis kelamin, tanggal lahir, berat badan, tinggi badan, riwayat obesitas orang tua, dan pendidikan orang tua. Uji statistic dengan 
regressi logistic binary metode backward: wald untuk mengetahui determinan kejadian obesitas pada anak usia sekolah.

\section{HASIL}

Metode analisis uji statistik regressi logistik binary metode backward : wald. mendesain variabel yang tidak berhubungan atau yang mempunyai hubungan yang lemah secara statistik secara komputerisasi akan dikeluarkan dari permodelan uji regressi. Pada analisis ini, dimasukan semua variabel bebas yang secara kerangka konsep teori berhubungan dengan obesitas pada anak usia sekolah, yaitu : jenis kelamin, ayah obesitas, ibu obesitas, ayah dan ibu obesitas, pendidikan orang tua, dan asupan energi harian. Hasil lengkap dari model akhir uji regressi logistik tercantum pada Tabel 4.1.

\section{Tabel 4.1}

Model akhir uji regressi logistik majemuk untuk variabel terpengaruh obesitas pada anak usia sekolah statistik dengan kejadian obesitas pada anak usia sekolah adalah asupan energi harian, ibu obesitas, dan ayah obesitas. Berdasarkan tingkat signifikansi maka variabel asupan energi harian adalah determinan obesitas pada anak usia sekolah di SD Al-Irsyad 01-02 Cilacap ( $p v=0,001$ pada $\alpha=0,05$ ).

\section{PEMBAHASAN}

Tabel 4.1 merupakan rangkuman model akhir uji regressi logistik majemuk. Berdasarkan hasil analisis terlihat bahwa variabel asupan energi harian merupakan variabel yang mempunyai hubungan paling kuat secara statistik dengan kejadian obesitas pada anak usia sekolah $(p v=0,001$ pada $\alpha=$ 0,05 ). Hal ini mengandung arti bahwa asupan energi harian yang melebihi AKG ( > $2.000 \mathrm{kkal} /$ hari ) adalah faktor utama ( determinan ) dari kejadian obesitas pada anak usia sekolah di SD Al-Irsyad 01 02 Cilacap Tahun Pelajaran 2017/2018. Hal ini dapat disebabkan karena tingginya asupan energi pada anak

\begin{tabular}{|l|c|c|c|c|c|c|}
\hline \multicolumn{1}{|c|}{ Variabel } & B & S.E. & $\begin{array}{c}\text { Wal } \\
\text { d }\end{array}$ & Sig. & $\begin{array}{c}\text { Exp opesitas yang tidak diimbangi dengan } \\
(\mathbf{B})\end{array}$ \\
\hline Asupan energi & 3,25 & 0,954 & 11,66 & 0,001 & 26,017 pembakaran energi dapat menyebabkan \\
\hline Ibu obesitas & 2,87 & 1,154 & 6,211 & 0,013 & 17,725 & penumpukan jaringan lemak adiposa \\
\hline Ayah obesitas & 2,62 & 1,162 & 5,087 & 0,024 & 13,761 \\
\hline Konstanta & $-8,979$ & 3,173 & 8,006 & 0,005 & 0,000 sehingga menimbulkan peningkatan berat
\end{tabular}
Logit $($ Obesitas anak usia sekolah $)=\mathbf{- 8 , 9 7 9 +}$ 3,25 Asupan energi harian + 2,87 Ibu obesitas + 2,62 ayah obesitas.

Tabel 4.1 menunjukkan variabel yang mempunyai hubungan bermakna secara badan (Misnadiarly, 2007).

Hasil penelitian ini memperkuat teori yang menyebutkan bahwa semakin tinggi asupan energi maka semakin tinggi pula kemungkinan untuk terjadinya obesitas 
pada anak dan remaja ( Kemenkes RI, 2014

). Menurut Raiz ( 2009 ), terjadinya kelebihan berat badan pada anak dan remaja dengan obesitas karena rata-rata mengkonsumsi $500-1.000$ kalori lebih banyak dari jumlah yang dibutuhkan setiap harinya. Berdasarkan hasil penelitian Sejati ( 2017 ) menunjukkan bahwa pola makan anak yang obesitas dan anak yang tidak obesitas terdapat perbedaan yang bermakna secara statistik pada jumlah asupan kalori per hari, yaitu rata-rata $2.546 \mathrm{kkal} / \mathrm{hari}$ pada anak dengan obesitas dan 1.995 kkal/hari pada anak yang tidak obesitas. Hal demikian menunjukkan bahwa konsumsi energi harian pada anak yang tidak obesitas hampir mendekati jumlah energi yang dianjurkan dalam Angka Kecukupan Gizi ( AKG ) untuk anak umur 10 -12 tahun, yaitu sebesar $2.000 \mathrm{kkal} / \mathrm{hari}$ ( Kemenkes RI, 2014 ).

\section{E. KESIMPULAN DAN SARAN}

\section{Simpulan}

Determinan kejadian obesias pada anak usia sekolah di SD Al-Irsyad 01-02 Cilacap Tahun Pelajaran 2017/2018 adalah asupan energi harian yang melebihi Angka Kecukupan Gizi atau > $2.000 \mathrm{kkal} / \mathrm{hari}$ $(p v=0,00, \alpha=0,05)$.

\section{Saran}

Orang tua dapat melakukan upaya pencegahan kejadian obesitas pada anak usia sekolah dengan cara mengatur pola makan anak agar asupan energi harian tidak melebihi AKG ( 2.000 kkal/hari ) .

\section{DAFTAR PUSTAKA}

Dinkes Kabupaten Cilacap. 2016. Profil Kesehatan Kabupaten Cilacap Tahun 2016. Cilacap

Kementerian Kesehatan Republik Indonesia. 2014. Pedoman Gizi Seimbang. Jakarta.

Kementerian Kesehatan Republik Indonesia.Dirjen Bina Gizi dan Kesehatan Ibu dan Anak. 2011. Pedoman Pencegahan dan Penanggulangan Kegemukan dan Obesitas pada Anak Sekolah, Jakarta :Katalog DalamTerbitan. KementerianKesehatan RI ISBN 978-602-235-038-5.

Kementerian Kesehatan Republik Indonesia. 2010. Profil Kesehatan Indonesia Tahun 2010.Jakarta

Misnadiarly, 2007. Obesitas Sebagai Faktor Risiko Beberapa Penyakit.Jakarta. Pustaka Obor Populer.

Raiz. 2009. Obesitas yang semakin mendunia. Bandung: PT Rosdakarya,

Riyanto, A 2011, Aplikasi Metodologi Penelitian Nuhamedika Yogyakarta.

Nadhiroh Sri, Suryaputra, Kartika.,. 2012. Perbedaan Pola Makandan Aktifitas Fisik Antara Remaja Obesitas dengan Non Obesitas. Makara Kesehatan. Departemen Gizi Kesehatan, Fakultas Kesehatan Masyarakat Universitas Airlangga. 